\title{
The Legal System for International Companies and Its International Influence
}

\author{
Ahmed Ragab Abdel Khaleq Korshom \\ Special Law Department, Commercial of Law, Cairo University, Cairo, Egypt \\ Email address: \\ ahmeddiver78@yahoo.com
}

To cite this article:

Ahmed Ragab Abdel Khaleq Korshom. The Legal System for International Companies and Its International Influence. American Journal of Operations Management and Information Systems. Vol. 6, No. 3, 2021, pp. 35-51. doi: 10.11648/j.ajomis.20210603.12

Received: May 28, 2021; Accepted: July 9, 2021; Published: August 24, 2021

\begin{abstract}
Investment has become the backbone of all sectors in the country, because by doubling the investments, this leads to an increase in the national income, which is the main financier of most sectors of the country, and therefore attracting foreign investments is of great importance in the development of the country. Countries, and because these investments will play an important role in developing those countries' investments through technology transfer, and companies play a major role in helping many developing countries in the world provide opportunities to penetrate the global market, for example: the experience of the Asian tigers in Southeast Asia, and therefore Developing countries must attract these international companies so that they can exit from the crucible of primary and extractive commodity production to industries that are more beneficial in terms of export value. Among the factors that led to the spread of global companies is the desire of countries, especially developing ones, to encourage investments through these companies due to their lack of capital for development programs, and the need for technical, technical and administrative expertise. The structures of these entities are highly organized, as most of these companies are managed from the countries of origin in the central method, in which the main center of the parent company is located. International companies are a huge force in the global economy, and they operate through a complex network of organizational structures, and they engage in international production processes according to an integrated global system, under whose management nearly a third of global production, and international companies are the main driver of the phenomenon of globalization, which represents the determinant The basic path of growth and development in various countries of the world today, and the emergence of global companies is the new form of organizing international economic activity, and these companies began to control the world, infiltrating all areas of national sovereignty.
\end{abstract}

Keywords: Investments, Financier, Technology Transfer, Regional and International, Companies

\section{Introduction}

\subsection{Booting and Partitioning}

Global companies are self-contained economic units, under unified control in order to achieve a unified global production strategy.

The most important characteristic of international companies is that they operate under a unified central control, and within the framework of a global strategy, which ultimately aims to increase the profits of the parent company, and therefore the activity of the fledgling companies in various fields is not determined according to the requirements of the national policies of the host country, but according to what It is necessitated by the interest of the multinational enterprise, which is mixed with the interest of the controlling parent company, the parent company and the fledgling companies may take different forms in line with the strategy of the parent company and to achieve its interests.

Since international companies are one of the most important legal, economic and even political phenomena in the post-World War II world, international companies constitute a new global phenomenon that transcends traditional legal concepts. International companies have an entity that transcends the territorial borders of the countries in which they operate.

These international companies have spread all over the world to create a kind of monopoly in multiple economic sectors, as many countries' legislations do not have legal rules governing this type of companies, which led to the exploitation 
of these international companies to achieve their interests; As a result of the discrepancy between these legislations to achieve their interests and not, they are interested in the negative effects that the activities of these international companies cause within the societies of those countries.

The emergence of this type of company is due to the merger system between two or more companies of two or more different countries, which led to the formation of gigantic economic units, and in turn helped the technological and technical development in the developed world.

\subsection{Research Importance}

These companies play another major role represented in helping many developing countries of the world to provide opportunities to penetrate the global market, for example: the experience of the Asian tigers in Southeast Asia, and therefore the developing countries must attract these international companies so that these countries can get out of the crucible for the production of primary and extractive commodities to the industries most advantageous in terms of export value [1].

The Arab countries have not benefited much from these companies in developing and developing their technological capabilities. All they have done is import ready-made technology, in order to manufacture for export. These international companies have played a major role in deepening the concept of globalization by pushing in the unification of competition in the markets for goods, services, communications and transportation.

Among the factors that led to the spread of international companies is the desire of countries, especially developing ones, to encourage investments through these companies due to their lack of capital for development programs, and the need for technical, technical and administrative expertise. [2]

This type of giant economic entities, when exercising their activities, exceed the regional and international scope, and the structures of these entities are characterized by a high degree of organization, as most of these companies are managed from the countries of origin in the central method, in which the main center of the parent company is located.

These companies are international in activity, consisting of a parent company stationed in a country called the state of the headquarters, and there are branches and fledgling companies affiliated with this parent company in other countries called the host countries.

The goal of these international companies is to obtain the largest amount of customs exemptions, privileges and profits, and these companies do not have any loyalty to any country despite their affiliation with the major developed countries of the world, in which the main center of the parent company is located, and these international companies have an economic role that leads to influencing the centers of manufacture The political decision in the countries in which the economic activity is carried out, especially the developing countries. This is due to the annual profits achieved by these companies, which may exceed the size of the national product of many countries.
It was necessary to shed light on this type of companies for their important role in the global and national economy.

\subsection{Research Aims}

This research aims to:

1) Knowledge of the legal composition of international companies.

2) Methods of forming international companies.

3) The impact of those global companies on the national and international economy.

4) The way these international companies work.

5) The role of these companies in the development of foreign direct investment.

\subsection{Research Problem}

Investment has become the backbone of all sectors in the country, because by doubling investments, this leads to an increase in the national income, which is the main financier for most sectors of the state, and therefore attracting foreign investments is of great importance to developing countries, and because these investments will play an important role in developing the investment of those countries through Technology transfer, which entails that the legislative investment policy of developing countries is characterized by flexibility and development that encourages attracting more investments without prejudice to the independence of the state, or its rights, which are originally the rights of society in all its categories, and the entry of these countries into regional and international alliances to develop investment in them [2].

Dealing with these companies has become an urgent necessity, given the role they play in the development of third world countries and developing countries, and what goes beyond that role in the aspects of the social and political life of the developing world countries.

\subsection{Research Methodology}

Foreign direct investment, especially international companies, plays a major role in the developing countries hosting such investments in terms of its effects on growth, production and technology transfer, so that foreign direct investment has become more important than traditional trade.

In this study, we will study that type of company, the parent company, and its nascent companies, and take a look at that integration and legal regulation between those companies and the general strategy that these companies set to achieve their interests, and accordingly it requires The study aims to discuss the legal composition of the organization of international companies, and accordingly, we will divide the study in this chapter into the following two topics:

The first topic: the legal regulation of the formation of international companies.

The second topic: the parent company's responsibility for organizing the fledgling companies. 


\section{The Legal Structure of Global Companies}

\section{Booting and Partitioning}

Today, global companies constitute the driving force in the current international economic and political system. From an economic point of view, they are considered important in the field of international relations, as they represent today one of the forces affecting the making of economic, social and political events and transformations in the contemporary world, and these companies have become controlling natural resources. They are enormous, and directly control the most important economic activities in all societies in the world. The growing influence of these companies has prompted them to find a kind of merger between production units and global financial and banking institutions at the global level.

International companies are a huge force in the global economy, and they operate through a complex network of organizational structures, and they engage in international production processes according to an integrated global system, under whose management nearly a third of global production, and international companies are the main driver of the phenomenon of globalization, which represents the determinant The basic path of growth and development in various countries of the world today, and the emergence of global companies is the new form of organizing international economic activity, and these companies began to control the world, infiltrating all areas of national sovereignty.

The legal structure of international companies consists of two economic components, which complement each other, first: the parent company and second: the fledgling companies and these two elements are the main components of international companies, and accordingly we will address these two components through the following demands:

The first requirement: the types of international companies.

The second requirement: the legal formation of the acquiring international company.

The third requirement: the legal formation of the subsidiary company.

\subsection{Types of Global Companies}

\section{Booting and Partitioning}

International companies take several different forms. Through these forms, it is possible to understand their legal system, and differentiate between them and other economic entities, which may be similar to them. We will explain each type separately through the following branches:

Section One: International Merged Companies.

Section Two: New Companies.

Section III: Acquisition of companies.

\subsubsection{Global Merged Companies}

The merger of companies is a process through which a legal link takes place between two or more companies who share the same specialization, so that those merged companies turn into one company, and control of the legal system of those merged companies becomes through the company that carried out the merger process, and those companies merged under its banner and control.

The European Parliament had a resolution issued on October 26, 2005, recognizing that the mergers of limited companies, partnerships limited by shares, limited liability companies, and partnerships limited by shares registered in France, in accordance with French commercial law.

This merger is considered one of the legal forms through which these companies are legally interconnected within a single entity that produce a unified production of products, or that these companies produce goods that complement each other.

The jurists defined the merger between companies as: "The meeting of two or more companies into one company, whether by joining one company to another, where the merging company loses its legal personality in favor of the merging or merging company. This is what is called merging by mixing.

Some legal scholars have defined the merger as: "the merging of one or more companies within another company, or the extinction of two or more companies, and a company transferring the funds of the companies that have disappeared to it." All of its assets and liabilities are transferred to the merging company, or two or more companies are dissolved accordingly, and the legal personality of each of them ceases, and they form a company with an independent legal personality, and all assets and liabilities are transferred to that new company.

The merger leads to the expansion of competition outside the territory of the state through the establishment of a branch or branches of the company outside the region from merging with companies of other nationalities located in those places, in order to control the market [3].

There are ways of the merger process, it may be through the inclusion, or the acquisition of a company for a group of companies, and the merger process may be through mixing those companies into one company, and the consequent dissolution of those companies, the formation of a new company, and the legal personality of those companies merged in those companies will disappear. The new company.

In international companies, the branches and agencies of foreign companies operating in a country based on its territory may be merged, and those branches and agencies will expire, and the legal personality of each of them will disappear, and this type of merger is resorted to by international companies to eliminate their competitors in the market, or this internal merger takes place to form Major national economies as large national companies to face global companies.

The intent of the merger of companies may be to achieve many goals, including:

It is a way for companies to escape from collapse and bankruptcy, and the merger also works to strengthen the state's economy and increase strong capital that enables it to maintain its internal markets and open new markets [4]. 
The motive for achieving integration, or motivated by competition, and may be resorting to merger to treat the situation of troubled companies, where companies, which suffer from economic crises or debts, resort to the path of merging with another company with high economic and better administrative capabilities

Overcoming competitor companies operating in the same field, by changing the forces of competition in the market, through a merger that occurs between a numbers of form companies with different nationalities, which leads to the emergence of global companies, and the real reason and motive for the merger may be the desire for control and monopoly.

The Egyptian legislator stipulated the process of merger between companies in the Egyptian Companies Law No. 159 of 1981, as amended by Law No. 3 of 1998, and Article No. (132) stipulated that the company resulting from the merger shall be considered a successor to the merged company and legally replace it with its rights, and what It has obligations within the limits agreed upon in the merger contract without prejudice to the rights of the creditors, and in accordance with Article (135) of the same law, the merger shall take place by a decision issued by the extraordinary general assembly of each of the merging and merging companies, or by the group of partners who own the majority of the capital [4]. According to French commercial law, the merger, if any in each of the companies participating in the merger process, is subject to ratification by special meetings of the shareholders of the merged companies, and the boards of directors or the management of each company participating in the merger shall inform the shareholders before the company's general board meeting resulting from the merger process from any fundamental change in its assets and liabilities, and an authorized representative for the merger will be appointed.

Also, according to French commercial law, it is not necessary to approve the merger by the extraordinary general assembly of the owner company, where one or more of the company's shareholders representing at least $(5 \%)$ of the capital can request the court to appoint a representative for the purposes of holding the general assembly meeting. Extraordinary procedures of the company for the purpose of obtaining a judgment approving the merger.

We believe that a merger can be defined as: "Transferring all the shares and shares of another existing company, so that its capital increases by the value of these shares and shares so that the existing company bears developing a strategy and managing the two companies together under one management, as well as bearing the obligations of the merged company, and it is responsible for claiming its rights under the One management controlled by the merging company.

\subsubsection{New Companies}

The French commercial law stipulates that the merger of companies is through a consensus among the general assemblies of the merged companies on the merger process, and the major companies carry out the process of merging between companies in order to maximize their entity at the international level through the formation of new, newly created companies [5].

And the merging company can take many ways to form its newly created companies, by borrowing from the internal market of the host country for the newly created company by issuing bonds, to be offered for public subscription, or by issuing new shares, the proceeds of which are used to finance these fledgling companies, but this depends on that the state does not place restrictions on the export of Capitals are abroad, and these fledgling companies can, by virtue of their holding the nationality of the host country, and the consequent enjoyment of the same rights as national companies, where they can resort to borrowing from the local market and finance their activities, and some countries may resort to placing obstacles in front of the parent merging companies so that they do not consume These companies are the dollar base of the host country, as the goal of mergers is to attract foreign capital, in order to pressure those merging companies not to borrow from the internal market to obtain their financing, in order to protect the balance of payments of the state, by preventing the export of funds outside the country.

In order for a major company to form new, innovative companies, two conditions must be met:

The first condition - that the merging company has full rights in accordance with national law to own the shares of another company.

The second condition is that the foreign merging company has control over the newly created company, within the territory of a particular country, by owning a high percentage of its shares.

With the development of legislation, it became possible for merging companies to own shares of existing companies, as there are no such obstacles for the merging companies to attract money from foreign investments, which enabled these merging companies to control those newly created companies, as the legal system of the newly established subsidiary An international company, in light of some legislation, enjoys a legal system that is relatively better and more liberal than that of the nascent company affiliated with purely national companies, due to the development of the administrative system of those international companies.

There is a conflict between the interests of international companies and the countries on their soil, the process of the merger and the creation of these new companies, since the international companies have the objective of creating these companies is to control the shares of the funds of these created companies, and this is what is opposed by some of the host countries whose idea is based on participation in controlling the Shares of these newly created companies.

And international companies prefer not to resort to the method of joint ventures with local companies, but in some cases these companies may be forced to follow this path, as if the implementation of the production strategy of the controlling company requires another company located in another country, as the parent company may not be able to buy all the shares of the company to be controlled, and 
therefore have to be satisfied with the amount necessary to achieve that control. But the general trend of these companies remains the rejection of joint projects, and this fully reflects the general trend we find in the policy of the host countries importing international companies, towards encouraging joint projects as a method of cooperation to form fledgling companies, and this trend appears more clearly in the policy of developing countries as reflected in their legislation regulating investments foreign capital.

It may be difficult for countries to establish effective control over international companies, given that the technical and technological capabilities are stronger among international companies, in addition to the need of the host countries for capital. Modern legislation allows the newly created companies to borrow from the local market, but according to some controls, in order to finance their projects, in in return for those new companies acquiring the legal personality of International companies and its acquisition of its name and its acquisition of the home of the global company.

\subsection{Acquisition of Companies}

International companies may resort to the system of acquiring other existing companies, in order to obtain technology, raw materials and goods produced by the controlled company, or for other reasons.

Acquisition in the field of companies means "that a company owns more than $50 \%$ of the shares of another company, which entails that the controlling company is affiliated with the controlling company, implements its economic strategy, and is subject to the decisions of the board of directors of the controlling company."

The strategy followed by international companies is not only in the method of forming new emerging companies, but these companies may resort to acquiring other companies that already exist, and transforming them into subsidiaries, and perhaps this method may become necessary sometimes if it comes to obtaining raw materials, or intermediate goods, produced by the company to be acquired.

And international companies are acquiring other already existing companies, for this they can only take one of two ways to achieve this purpose; Either you resort to forcible acquisition, i.e., against the shareholders who control the company, in the manner in which political revolutions take place to control the reins of government, and this method is called in French jurisprudence control by coup method, or you resort to controlling the company "by peaceful way" By agreeing with a group of controlling shareholders to transfer control to it, and the controlling shareholders of the company must not own more than $50 \%$ of its shares, as it is impossible in this case to transfer control without their consent and for this method to succeed, two conditions must be met:

The first: That the shares of a company be purchased in a short time, and in a way that does not raise doubts for the shareholders.

The second: the purchase of shares in a way that does not lead to a much increase in their prices in the financial market, so as not to increase the financial cost of the seizure. The development of the arts and methods of dealing in the stock exchanges today helped in the completion of such operations.

\subsubsection{Forced Acquisition}

According to this method, the acquisition is achieved through the establishment of some controlling shareholders who contribute less than $50 \%$ of the capital of the controlled company, while the rest of the shares are distributed among a large number of small shareholders.

For the success of the acquisition process, it is required that it take place in secrecy or through limited and trusted intermediaries, and they resort to many technical methods in the market to achieve such control, for example: that the purchase be made at a high speed, and suddenly without the rest of the shareholders noticing it so that they cannot That they take any countermeasures, enabling them to stop that control by buying the company's shares for their own account, or making a counter front from the small shareholders against that control, or that the shares are bought in a way that does not lead to a rise in the prices of those shares, which may lead to an increase in that of the cost that lies above the shoulders of the world [6].

The international company announces its desire to buy the shares of the company to be controlled, and it presents a specific offer in a specific period of time, at a specified price, or exchanging these shares for the shares of the international company presenting the offer. The submitted price is more than the share price in the stock exchange. In France, the application is submitted to the authority supervising the operations of the stock exchange in England. The application is submitted to the stock exchange's board of directors, and it is through a bank that acts as an agent for the offer owner.

International companies usually resort to the method of buying by public offer, in the event that there is no liquid funds available to purchase the shares of the companies they want to control. From his offer, by any advertising means, and with the end of the specific offer for the public offer, the concerned authorities shall investigate the availability of the minimum number of shares required to be purchased.

\subsubsection{Control by the Peaceful Way}

International companies may wish to resort to the use of the peaceful way to control the company, and this method means that a natural or legal person, in agreement with a group of shareholders controlling a company, transfers that control to that natural or legal person.

This transfer of control may take one of two forms; Either transferring partial control, in which case the control is divided between the previous first shareholders who had taken full possession of the company, and between the new shareholders who shared that acquisition with the previous shareholders.

The old shareholders usually resort to relinquishing control of the company in favor of another company due to the inability to compete with that other company, or that the offer made by the new shareholders is so tempting that the old shareholders prefer to give up that control, and most 
legislations do not include any regulation of the transfer process. Control or transfer of control, most contemporary legislation includes procedures that regulate the process of transferring control in order to preserve the interests of the parties to the process, especially the shareholders and creditors of the merged company.

Accordingly, I believe that national legislation must regulate the process of corporate acquisition, and depend on the national benefit by ensuring the process of control brings benefit to the national economy, and not just random operations that enable international companies to control national companies depending on the availability of purchasing power to control in order to achieve huge profits. For international companies as a result of monopolizing certain goods produced by these national companies thanks to these acquisitions, the process of acquisition in international companies proceeds in random and unorganized ways, depending on Purchasing power, without taking into account the economic interest of the countries on whose territory the process of control took place, which may negatively affect the economies of those countries.

\section{Legal Composition of the Global Acquiring Company}

\section{Booting and Partitioning: [7]}

Knowing the legal regulation of the parent company is the basis for understanding the legal regulation of international companies in general; This is because the parent company sets the general strategy of the global company, and through it takes all the important decisions. Therefore, we will shed light on the legal organization of the parent company through the following branches:

Section one: Subsidiaries.

Section Two: Establishment of new companies.

Section Three: The legal composition of the acquiring holding company.

\subsection{Following Companies}

The formation of subsidiaries on the territory of the host country enables them to acquire the nationality of those countries, which enables them to easily deal with the authorities and laws of that country, which helps in facilitating the company's activity. Subsidiaries can be defined as: "Companies that engage in productive activity in different countries and are under the control of a company. One, known as the parent company, which controls its management and development of its production strategy.

And we see that international companies control the subsidiary company administratively and financially, as it is a relationship in nature, a financial and administrative relationship, and in view of this relationship on the part of the subsidiary company, it can be characterized as a dependency relationship, because the subsidiary company follows the parent company financially and administratively.

According to the French Companies Law, when a company owns more than half of the capital of the second company, the second company is affiliated with the first company, which acts as its parent company, and to ensure that the subsidiaries adhere to the strategy of the parent company, it appoints members of the board of directors of the subsidiary company for the purpose of controlling it, from During the development of the investment and financial policy, and the development of the production plan, and to control the management of the subsidiary company, it is through the parent company owning $(51 \%)$ or more of the shares of the subsidiary company, so that it can acquire most of the votes in the board of directors of the subsidiary company [8].

The acquiring global company and its subsidiary company operate in the same place, or in the same business, so that it is possible that the two companies are competing in the market, and the parent company can direct the subsidiary company to serve its interests, and the subsidiaries are spread in many countries, which may be geographically far from the company The mother, but it revolves in its orbit, and works to implement the economic plan set by the parent holding company, and the source of the relationship between the international company and its subsidiaries is what the acquiring global company owns of shares in the capital of those companies, which enables the parent company to control them, so that it works Subsidiaries are in accordance with a comprehensive work plan set by the acquiring company to achieve more profits. The acquiring global company works on managing a specific strategy, which all subsidiaries are committed to.

The acquiring global company intervenes in the financial policy of the subsidiary company, and imposes continuous control on it. In return, it is any parent company that finances and lends the subsidiary company, and it unifies the financial budget of the subsidiary company with its counterparts from other subsidiaries of the acquiring company in order to serve the general strategy set by the company It also determines for each of its subsidiaries the amount of profits to be retained as a cash reserve.

The Egyptian legislator must also regulate the relationship between the parent company and its subsidiaries in international companies, and regulate it accurately and with clear and explicit texts, and according to that financial and administrative control by the parent company over its subsidiaries, and that control determines the strategy of the subsidiary company and its commitment to it even if this leads to that. To harm the host country, such as transferring most or all of the profits achieved by these subsidiaries to the countries of the parent company, which requires the Egyptian legislator to regulate this relationship legally in a way that ensures that the Egyptian economy is not harmed when these companies start their activities on Egyptian lands.

These subsidiaries derive their nationality from the nationality of the acquiring international company and identifying that personality facilitates many problems when the acquiring company establishes subsidiaries, or fledgling companies, and the parent company is concerned with 
decisions of a strategic nature that relate to the basic aspects of the activities of the subsidiary company, while decisions of an executive nature are made Leaving it in most matters to the boards of directors of those companies, and this varies from case to case, according to the strategy set by the global acquiring company for its subsidiaries, and from here, the global company strengthens its administrative control of those subsidiaries, so that it leaves it only a small trace of independence for its subsidiaries in manage its affairs.

And the international company controls the management of the subsidiary company, this does not mean that it can control all the joints of the subsidiary company and the subsidiary company's equipment, and that is when the parent company owns a not large proportion of the shares of the subsidiary company, but it enables it to control the decisions of the subsidiary company with that simple majority, and that is through its representatives on the board of directors of the subsidiary company, and this control increases little by little as the proportion of the parent company's contribution to the capital of the subsidiary company increases, and the importance of such control is negated in the case of the global company's ownership of the capital of its subsidiary company in full.

The acquiring international companies can use the assets of the subsidiary company, or use the trademarks owned by the subsidiary company. The use of the international company's funds of the subsidiary company is not opposed by any of the texts that regulate the acquired holding companies, and we believe that this could lead to a confusion between the legal personality of the subsidiary and the personal the moral of the parent company for a holding that it controls, the central management is by the parent company of its subsidiaries. From our side, we believe that in order to avoid this mixing, the legislator must regulate the method of using the parent holding company for the material and moral funds of its subsidiary company with legal texts through which agreements are concluded between the acquiring global company and its subsidiary company, it can from exploiting its material and moral funds, in order to maintain the independent legal personality of the subsidiary company.

\subsection{Creating New Companies}

The international company establishes new companies. These companies acquire a legal personality independent of the international company, and the parent company has full control over the newly created company.

Many international companies resort to this in the event of great competition from a national company, so they work to buy shares in that company, and a new company is formed affiliated with the mother international company in order to contain that competition, or from buying all the shares of the national company, and directing its economic policy to achieve It corresponds to the economic policy of the parent company that owns those shares, and here that control is achieved.

And when the international company finds it difficult to own the appropriate amount of company shares, enabling it to control that company due to economic or political factors within the host country, or because the laws of the state or the laws of the company do not allow it to own that amount of company shares, this may be done by achieving a majority Voting within the board of directors of the company to be acquired and directing its policy, and the parent company can establish new companies, acquire an independent legal personality, name and domicile, and have financial rights such as the right to borrow from local markets to finance its activities. During the issuance of bonds that are put to general depression, or by issuing new shares, however, some countries-imposed restrictions on the right of the emerging companies, which are subject to foreign control, in order to force these companies to borrow from the acquiring company [9].

The newly established companies spread globally are subject to unified financial and administrative control, which is a vital necessity to achieve the unified global production strategy for international companies, and that strategy is presented on the basis of serving the interests of the multinational enterprise as a whole, which eventually mixes with the interests of the dominant global company without regard to the partial interests of the emerging companies And international companies to achieve their strategy, often at the expense of the host countries, and these methods, with their diversity and differences, ultimately depend on the control exercised by the international company over the financial receivables of its newly created companies, which allows it to apply to these receivables.

Where the acquiring global company can, according to its interest, transfer profits and various financial assets from one company to another, through exchange operations that take place between these companies or through other contracts concluded by the fledgling companies between them, or between them and the parent company, or This is repeated by other methods, and there is no doubt that the overall global strategy of international companies, based on achieving the interest of the acquiring company, without considering the partial interests of the newly created companies, would also often harm the interests of the creditors of these companies, and that the risks to which it is exposed The creditors are due to the overlap, or mixing, between the financial receivables of the fledgling companies and the parent companies, with the consequent possibility of transferring financial assets from one company to another as we have indicated, according to the interests of the multinational project, that is, in the end, according to the interests of the company. the mother.

The newly created company is characterized by an independent legal personality, with its financial liability separate from that of the controlling parent company, which means that the global company is not responsible for the debts of its subsidiaries, and despite the fact that control leads to an abuse of the exploitation of the newly created companies from the administrative and financial aspects, and the law is still Positive in most countries of the world, these companies are seen as independent legal entities, each with 
its own free and independent will and separate financial liability, and then the parent company can exercise its control over the financial receivables of its fledgling companies in the ways and methods we mentioned.

The group of companies must be viewed as an integrated unit, in which authority is linked to responsibility, with the consequent need to consider the acquiring company responsible for the debts of its newly created companies, and the financial receivables of the newly created companies overlap with the consequent need to consider the creditors of the companies as creditors of the whole group, except Such a solution, even assuming its approval at the internal level, will remain ineffective for international companies operating at the international level, due to the inability to link this new legal entity to a unified legal system, and that the global strategy of international companies may conflict with the interests of workers in the production units that The fledgling companies are managed, and this overall strategy can lead to sacrificing the interests of the fledgling companies, and the interests of their employees.

It may be in the interest of the acquiring company, for example, to close some export markets in front of one of its fledgling companies for the benefit of another fledgling company, for tax, economic or political reasons, with the consequence of the necessity of closing some of the company's facilities to which export markets were closed, and laying off its workers. In fact, the source of danger the main threat that threatens the interests of workers in the newly established companies, as is the case with the creditors and shareholders of these companies, enables all decisions related to the activities of these companies to be subject to the requirements of the overall interest of the multinational project, which often leads to sacrificing the interests of some of the newly established companies.

Labor law scholars are working on studying the best ways to protect the interests of workers in the production units of international companies, to follow the same path that commercial law scholars have taken with regard to the shareholders and creditors of the fledgling companies, and by this we mean an attempt to transcend the legal boundaries that separate the various fledgling companies between them and the parent company. The limits established by the traditional theory of legal personality, and whatever the amount of protection that can be provided to workers in the fledgling companies, using this or that technical method, the international companies with their current structure and existing legal system will remain a source of many labor problems.

\subsection{Legal Composition of the Acquiring Holding Company}

There is no specific definition given to the holding company, but many legal scholars call it the "mother company" as this parent company contributes to the establishment of a company or other companies under its control, and it is called the fledgling company or subsidiary company, through the establishment of that company The parent holding owns a large proportion of the capital of the subsidiary company, and the holding company is nothing but an integrated economic group, consisting of a mother company that controls a group of subsidiaries, and accordingly we can say that the holding company is: "that parent company, which controls a group of companies Subsidiary, and it may be called the holding company and as: it is the controlling company, which takes control of a group of companies by owning a large percentage of the capital of those companies.

Some define it as: "A company whose main or only activity owns a portfolio of securities, and its management represents its participation in the capital of other companies, and it is called the fledgling companies."

Or as: "The company that controls another company so that the first takes over the management of that second company. Some define the holding company as a company that owns shares in several other companies called subsidiaries to the extent that it can control the management of the company and it is the one that manages the subsidiaries, and how Managing and managing the affairs of subsidiaries.

The purposes of the holding company and its subsidiaries may differ, but there is an integrated economic unit between them, despite the different opportunities; Others may define a holding company as: (a company whose main or sole activity owns a portfolio of securities, and its management represents its participation in the capital of other companies, it is called the fledgling company), where some see it as the parent company that controls a company or subsidiaries By owning shares in its capital, and another side sees it as a parent company that controls a company, or subsidiaries, by enabling it to direct the subsidiary company in the direction that achieves its interests.

Some have defined it as that type of company whose sole purpose is to exercise control over other companies by owning shares in their capital without engaging in any industrial, commercial or financial activity [10].

The difference in the definition of the holding company is due to the different angle from which the holding company is viewed. We see that some of the French jurisprudence believes that the criterion in defining the holding company is due to the independence of the legal personality of the subsidiary company from the legal personality of the parent company. Legally separate from each other, and at the same time linked to each other, one of them is considered a parent company or a controlling company with the ability to impose unity of decision on the member companies of the group that find themselves in the position of the subject.

While the "Anglo-American" jurisprudence sees that the holding company is the parent company's control over the subsidiary company, through its ownership of a large percentage of the subsidiary's capital shares, while another aspect of jurisprudence sees that the holding company is the parent company's control over its subsidiary company through its monopoly on the right to appoint members The board of directors of the subsidiary company to obtain the majority of votes in its board of directors and to direct the 
policy of the subsidiary company to serve its interests.

Another aspect of French jurisprudence sees that the holding company is a group of legally separate companies, one of which is the parent company, or the controlling company, and it has the ability to impose its decisions on other companies by buying or subscribing to the shares of those controlled companies. The French jurisprudence defines a holding company as a company that owns shares in several other companies called subsidiaries to the extent that it can control the company's management, by deciding who is in charge of managing the subsidiaries, and how to run or manage the affairs of the subsidiary company.

The Egyptian legislator stipulated in Article No. (1) of Law No. (203) of 1991 AD regarding the issuance of the Public Business Sector Companies Law that the holding company takes the form of a joint stock company, and is considered a private law person, and the holding company invests the money of the subsidiary company, as the company has Holding in accordance with Article No. (2), in order to achieve its objectives, it does the following:

1. Establishing joint stock companies alone, or jointly with legal persons or individuals.

2. Buying or selling shares of joint stock companies or contributing to their capital.

3. Forming and managing the company's stock portfolio, including shares, financing instruments, bonds, and any other financial assets.

Article No. (16) of Law No. (203) of 1991 states that (the company is considered a subsidiary in applying the provisions of this law to the company in which one of the holding companies has at least $51 \%$ of its capital) and based on that article, the company is considered a holding company in accordance with the previous law If it owns at least $51 \%$ of the shares of the subsidiary.

Through these definitions, we can limit the concept of a holding company to the fact that it is a company that absorbs any commercial company, whether it is a company of people or money, and it has the right to control its other subsidiaries, through the holding company owning the majority of the voting shares in its subsidiary company, and from Then the holding company can choose most of its members The board of directors of the subsidiary company, so it is able to control the subsidiary company, by directing its policy, and appointing and dismissing most of its board members, if not all of them, because it has such a high percentage that enables it to vote on the board of directors of the subsidiary company in a way that serves its interests.

International companies consist of economic units that take different forms. The head office may be a company or an office headed by a manager who manages a number of companies in multiple countries. Some see that international companies are multiple entities, each with its own independent identity and independent home [11].

International companies may also be established through multiple companies regulated by certain legal rules, such as a holding company, and may arise from a contractual relationship as a result of a country's need for a certain technology or funds available in another country, so a contract is made between them to invest in an economic project in a third country, and may arise International Companies Activity through an international agreement between more than one country. Therefore, we find here that international companies have a larger and broader concept than the concept of a holding company.

This difference between the two types of companies, despite the similarity between them in that both are based on the unity of leadership and dominance, which leads to the mixing of the two concepts of companies, they differ in that the scope of the activity of the holding company is within the territory of a single state, while in international companies the activity and despite taking the same methods Holding companies, however, their activity extends to the territory or regions of other countries, and the holding company controls subsidiaries that are legally independent from them, but in international companies it dominates over companies that may be legally independent from them, the holding company may be similar in concept with the concept of other companies as a result of the existence of A kind of economic bloc in those companies, as well as a kind of rapprochement that led to the mixing of the concept, and accordingly we will clarify the difference between them as follows:

In a holding company, the parent company is in a specific country, and it manages its subsidiaries in other countries, thus it is considered an international company, but there are differences between the holding company and the global company.

When distinguishing between the holding company and the investment company, both the parent company in the holding company and in the investment company own shares in a company or other companies, but there is a fundamental difference between, which is that the parent company in the holding company aims to own those shares is to impose hegemony and control over those companies As for the investment companies, the parent company in them, the objective of owning those shares in other companies is to invest with the aim of obtaining a percentage of the profits, and therefore the criterion here is control, and accordingly, if there is control, the company here is a holding, and many legal scholars believe that If this percentage is high out of the company's capital, this means that it is moving towards control, but if the percentage is lower, the indicator indicates the intention to invest.

I criticize this result, as the investment company owns a high proportion of the company's shares without having the intention or intention to control, and in my opinion, the intention to control and disclose it through the share ownership percentage is through the parent company directing the company's decisions through its ownership of that high percentage of shares. stock.

When distinguishing between a holding company and a sister company, the company is a sister company to another company, in the event that the members of the board of directors in one of the two companies are the same as the members of the board of directors of the other company, 
although both companies are independent of each other, but the characteristic that distinguishes the holding company from the sister company is control the parent company is a subsidiary or a fledgling company.

When distinguishing between the holding company and the producers' agreement, the producers' agreement is an agreement between two or more companies, and the goal of this agreement is to develop a unified strategy on issues related to the two companies, such as agreeing to unify prices, or divide the geographical control of the market between them, or Determining production among themselves, or dealing in certain commodities, but this type of agreement does not find a place for it because many countries have enacted laws that prevent monopoly, or prevent agreements that prevent legitimate competition between companies.

\subsubsection{Methods of Acquisition by the Holding Company of Its Subsidiaries}

(A) The acquisition by the holding company of a large percentage or majority of the shares of the subsidiary company:

The holding company controls its subsidiary company, so it must own a number of shares or shares in the capital of that company to the extent that it can obtain a large number of votes within the board of directors of this company or within its general assembly, which enables it to control the decisionmaking authority within that company. company.

We see in the amended English Companies Law in 1989 $\mathrm{AD}$ that it defined the holding company as: (The holding company is the one who owns more than half of the shares of the capital of a company or other companies or controls the formation of its board of directors), and the French Companies Law defines the holding company as: When it directly or indirectly acquires part of the capital of another company, it gives it the majority of voting rights in the company's general assembly).

It appears from these definitions that one of the means that enables the holding company to control a subsidiary company is to own a percentage that exceeds more than $50 \%$ of the capital of that company, which enables it to appoint the board of directors of the subsidiary company, and this board works under the direction of the holding company despite the company's enjoyment Legally affiliated with an independent legal personality [12].

During the establishment stage of the company, the holding company enters as a partner in the subsidiary company, i.e. it is one of the founders of that company, or owns the majority after the establishment of the subsidiary company, and that is either through participation in the subscription when increasing the capital of the company to be controlled or subscribing to the bonds issued by The subsidiary company, then these bonds are converted into shares, as the subscription enables the subscriber to have the right to vote, and thus achieves You have control over whether this subscription has reached a limit that enables it to obtain the largest amount of voting, but when subscribing to bonds, it is just a debt owed by the subsidiary company. If it is converted into shares, this leads to an increase in the capital of the subsidiary company from which that subscription was issued. These bonds are transformed from mere debt owed by the subsidiary issuing the subscription to capital shares.

The holding company is working on buying any shares that enable it to obtain the largest number of votes, which will enable it to form the majority in achieving the desired control. These shares may have multiple votes, or what is called (preferred shares), but if these preferred shares have no votes and its advantage is limited to the priority of obtaining profits, so the holding company does not seek to buy it, because it does not enable it to obtain votes that account for the majority of voting within the general assembly of the subsidiary company, which does not enable it to impose the required control.

This ownership is indirectly through a holding company over a subsidiary company, then that subsidiary company arrests a second company, and this second company arrests a third company, which is affiliated with the second company, and so on, and the first holding company is called in this case (the company The higher holding company) and that the first holding company will control all the other companies, and those companies will be affiliated with the first holding company, and the holding company may appoint one or more natural or legal persons who own most of the shares of other companies so that that natural or legal person becomes an intermediary for the holding company, and implementing its instructions, thus achieving the indirect ownership by the holding company of the majority of the capital of those companies through these intermediaries.

This is what we see found by companies with international activity through their establishment of intermediary companies within each geographical area, and these intermediary companies form other companies or control other companies in one or more countries within that geographical area, thus these companies become international activity and it is the supreme holding company For the intermediary companies and for those subsidiaries of the intermediary companies, and this majority ownership may be through buying shares of a company that has been established. The holding company buys the shares and shares of the capital of that company, to the extent that the holding company can dominate and control that company [13].

(B) Acquisition of the management of the subsidiary company:

The holding company can impose its control and hegemony over the management of the fledgling company or to be controlled through the holding company owning $51 \%$ or more of the shares of that company to be controlled, which enables it to acquire the majority of the votes in its general assembly, so it can control the decisions of the subsidiary company and isolate Appointment of members of the board of directors.

And part of the jurisprudence sees: that this control may be by the method of merger, which is that an agreement occurs 
between two or more companies to dissolve themselves, and the assets and debts of each of them are transferred to the new company that is established on the ruins of the dissolved company. Then the two companies are affiliated to another company located abroad, which creates an international company.

An opinion in jurisprudence goes that the company is considered a holding (if the company can appoint or dismiss most or all of the board members of the company to be controlled, without the need for the approval of any other shareholder, or if the appointment of members of the board of directors of the company that is considered affiliated, requires The approval of the company that is seen as a holding company, or if the appointment of the members of the board of directors in the company to be controlled is done in an automatic way to appoint the members of the board of directors of the holding company, as a result of the stipulation in the system of the company to be controlled, provided that all or most of the members of the board of directors of the holding company are considered Also members of the board of directors of the company to be controlled).

Another aspect of jurisprudence believes that the holding company can control, despite its ownership of less than $50 \%$ of the capital of the subsidiary company, based on contractual agreements between the shareholders, if they are not familiar with the company's policies, or they do not want to indulge in the administrative matters of the policy of the subsidiary company. And that most of their desire is to get the highest percentage of profits.

\subsubsection{The Legal Effects of the Holding Company's Acquisition of Its Subsidiaries}

The holding company has the right to have the power to impose its administrative and financial control over its subsidiary company, despite the independence of the legal personality of the subsidiary company from the legal personality of the holding company, which is only legal independence that does not depend on reality, and this leads to the occurrence of a liability for the holding company towards its subsidiary company.

(A) Legal effects resulting from the management of the holding company for its subsidiary:

The holding company is considered responsible as a manager of its subsidiary company, and if the holding company owns the majority or all the shares of its subsidiary company, it enables it to appoint or dismiss members of the board of directors of its subsidiary company, as well as enables it to control its management so that we can describe it as the manager and that what he does The manager's actions related to the company The French Court of Seine held the holding company responsible for the debts of the subsidiary company in what is known as the dominance of the "project master", where the parent holding company dominates the capabilities of that subsidiary company, and the administrative control exercised by the holding company over its subsidiary company or for An intermediary way, which makes the directors of the subsidiary company subject, when exercising their activities, to the control of the board of directors of the parent company.

The subsidiary company appears as a front for the parent company, and since the parent company owns most of the capital of the fledgling company, its financial liability appears to be mixed with the financial liability of the fledgling company, and the balance sheet with its profits and losses appears to be the same in the two companies. The holding company expresses its will through a natural person, who manages the subsidiary company and based on what the holding company owns the company appoints persons to represent it in the subsidiary company's board of directors, and therefore it is responsible for their actions.

(B) Effects of the holding company as a shareholder in the subsidiary:

The holding company and the subsidiary company together represent an integrated economic unit, in which the budget of the holding company and the subsidiary company are mixed, so the budget of the holding company is in fact the summation of its budget and the budget of the subsidiary company, as this mixture between the budgets of the holding company and the subsidiary company leads to the responsibility of the holding company towards the debts of the subsidiary company, and this led some to say that the court has the right, in the event of debts owed by one of the subsidiaries, to take collective measures against the group of companies that make up the holding company, as it is a single economic unit, despite the fact that each of them is considered an independent company.

In my opinion, although the basis is the independence of the legal personality from the personality of the holding company, the responsibility of the holding company for the debts of the subsidiary company is not sufficient due to the mixing of the holding company's finances with the finances of the subsidiary company only, but also that another condition must be met which is to achieve financial and administrative control over the subsidiary company. by the holding company, which because of that control directs the financial policy of the subsidiary.

The holding company transfers the profits of the subsidiary company to its own accounts, so it bears the responsibility for the debts of the subsidiary company, as a result of the fact that the balance sheet of the holding company and the subsidiary company meet in the accounts of the holding company, and therefore this financial and economic mix of the two holding and affiliated companies made the holding company responsible Regarding the debts of the subsidiary company, and in practice, the demand of the holding company to pay the debts of the subsidiary company is not resorted to if the financial position of the subsidiary company is good, but if the financial situation of the subsidiary company is deteriorating, the holding company is required to pay those debts based on the unit of financial responsibility between the two companies.

\subsubsection{Legal Composition of the Subsidiary}

In the definition of the subsidiary company, it is the 
company that is controlled by the parent company, and the subsidiary company is also called the fledgling company. Whether its name is a subsidiary company, or a new company, both names refer to a company that is controlled by the holding company, and a dispute arose in the jurisprudence On the definition of the subsidiary company, and if they agree on the necessity of having an element of dependency between the subsidiary company and the subsidiary company, and if they differ on the basis upon which that dependency is justified.

Some say that this basis may be caused by the contractual system that took place between the subsidiary company and the subsidiary company, and we do not agree with that opinion, as the establishment of the company may be contributed by more than one legal person, and according to this opinion, the dependence of the company is common between these founders and there is no A certain party assumed that control, and part of the jurisprudence believes that the basis for achieving the process of subsidiarity is to establish a state of dominance and control, when the subordinate company establishes the subsidiary company, and we, as we have already said, do not have to participate in the establishment as a reason for creating a dependency relationship.

And part of the jurisprudence sees in defining the subsidiary company as: "Those that are subject to the invested and stable financial control of another company, and what is meant by financial control is that which results from owning a certain percentage of the company's capital, and another side of jurisprudence sees that the subsidiary company is the company that is established between them. And between another company, the other company owns a large percentage of the shares of the subsidiary company and participates in its establishment, and that other company manages the subsidiary company and directs the decisions of its general assembly.

And also defined by Egyptian Law No. (203) of 1991 AD regarding the law of public business sector companies in Chapter One (subsidiaries) Article No. (16) as: They are those that have at least $51 \%$ of their capital, alone or jointly with a company or companies. Other holdings, or public legal persons, and in the latter case, a decision is issued by the Prime Minister to determine the holding company and that holding company invests the money of the subsidiary company, and accordingly, according to this article in the previous law, the company is considered a subsidiary if it owns a holding company of at least $51 \%$ of its shares.

And that a company's contribution to the capital of another company may not be intended to dominate or dominate this company, but rather the goal of this dependency and contribution is just a financial investment, and the goal of that contribution may be to create a kind of relationship that links the two companies through the establishment of a company. Participation in the establishment of that company, and its purchase of appropriate shares of the shares of that company, and its purchase of appropriate shares of that company's shares in the stock market, which enables it to control that company, and to control the company's decisions through the direction of its board of directors [14].

We believe that the best concept for defining the subsidiary company is the definition adopted by many jurisprudences, which is (that the subsidiary company is the one that is under the control of another company, because the latter owns all and most of the shares or shares of the capital of the first company, or the holding company controls the board of directors of the subsidiary company. Which takes the decision-making, controls its decisions, and directs the policy of the subsidiary company to serve its interests). Article 58 of the Rome Agreement establishing the European Common Market defines it as that company that contributes to another company, and that it must be established in accordance with the formalities and procedures stipulated in the member states. Its principal place of management must be in a country in the European Common Market.

The Egyptian legislator went in the Companies Law No. 159 of 1981 in his definition of the subsidiary company that this company exists in three cases:

The first is the company controlled by another subsidiary of the controlling holding company.

The second: It is the company for which a judgment is issued A judicial authority authorizing the company to have control over it in terms of management.

The third: The company in respect of which a court ruling is issued authorizing another company to control it in implementation of certain agreements.

The subordination of the subsidiary company to the control of the holding company is one of the most important characteristics of the subsidiary company, which is the basis for its subordination. The subsidiary company is subject to the holding company through either the holding company owning all or most of its shares and shares, or through the holding company controlling the company's board of directors.

One of the most important features of the companies headed by the holding company is the unit of control exercised by the holding company over its subsidiaries, which is imposed by the international strategy from an economic point of view. The subsidiaries are in fact just economic systems that complement each other economically, and they run according to the strategy set by the holding company. This is evident from the administrative centralization followed by the holding company in managing its subsidiaries through dominating the various aspects of the activities of its subsidiaries, by monopolizing the authority to issue decisions related to the activities of these subsidiaries.

The holding company is working to increase its profits through the application of a unified strategy that controls all its subsidiaries, so that the combined efforts of those subsidiaries and spread in many countries of the world will lead to no consideration for their own interests or the interests of the host countries in which these companies operate, hence the intervention of the holding company appears In the management of financial and administrative subsidiaries. 
Holding companies intervene in order to control the management of their subsidiaries through the so-called centralization of administrative control, and this does not mean that the holding company is in control in making decisions about its fledgling companies that it takes all the daily decisions related to managing the affairs of the subsidiary company, but it only monopolizes decisions of a nature The strategic, which is related to the basic aspects of the subsidiary company without the decisions of an executive nature that are usually left to the boards of directors of the subsidiary company, and the holding companies when they undertake the general policy of the activity of their subsidiaries. Therefore, the holding company must have the intention of controlling the subsidiary company through its ownership of most of its shares or All of them and not losing the intention of investing money, as well as the monopoly of the authority to issue decisions, appoint and dismiss members of the board of directors, and control the decisions of the subsidiary company in line with the strategy of the holding company.

And the holding company, although it is in control of the subsidiary company, this does not mean that it controls all the capabilities of the subsidiary company, and this becomes clear when the holding company owns a not large proportion of the shares of the subsidiary company, but it can control the decisions of the board of directors of the subsidiary company by a simple majority, and in case The holding company owns all the shares of the subsidiary company, so there is no room for the importance of oversight, because in this case the members of the board of directors of the subsidiary company, who are mostly shareholders of the holding company, will manage the subsidiary company according to the strategy set by the holding company.

When the holding companies develop their economic strategy for their subsidiaries, they play the role of continuous and regular monitoring of their subsidiaries, in order to verify that their subsidiaries implement this strategy, by regularly evaluating the performance of these companies, and to facilitate the task of the holding company in the control process. Subsidiaries follow the same accounting methods as the holding company, or the subsidiary company sets its accounts in the currency of the holding company.

B- Legal independence of the subsidiary:

The subsidiary company enjoys a legal personality as it has an independent legal presence such as the name or address, which distinguishes it from other establishments, and is subject to legal provisions different from the holding company. One of the effects of the legal personality of the subsidiary company is that it has a nationality.

Jurisprudence adopts different criteria to determine the nationality of the company. The nationality criterion may be in the location of the company's activity, meaning that the company takes the nationality of the country in which it operates, while another standard goes to adopting the location of the company's headquarters, where it takes the nationality of the headquarters country, and the nationality criterion may be the nationality Capital, and accordingly, the nationality of the company is the nationality of the country in which the company appeared under its laws.

As for the company, its domicile is the place where the company's head office is located, and the domicile serves as an address for the company or correspondence, or to file cases, or to determine the competent court for lawsuits, or bankruptcy. It also enjoys legal capacity within the limits and purposes set by the law, as well as its acquisition of rights, and the assumption of the obligations that fall upon it on the occasion of its activity, as well as the capacity [15].

If the principle is to respect the independence of the legal personality of each of the holding company and the subsidiary company, then there may be financial and economic overlap between the two companies because of the holding company's control over the subsidiary company, which makes the holding company responsible for the debts of its subsidiary company, and in fact, the creditors of the subsidiary company do not resort to To collect their rights from the holding company if the financial position of the subsidiary company is good, and it is able to pay the debts to the creditors, but if the financial situation of the subsidiary company deteriorates, the creditors demand the holding company for their rights and debts before the subsidiary company, according to the unit of responsibility between the holding company and its subsidiary company.

So, the company's money is the property of the company, and it is not considered common money among the partners, just as the company's money is a guarantee for its creditors, so the partners' creditors are not able to seize it depending on the debtor partner having a share in the capital, and no clearing takes place between the company's debt and the partners' debts.

Partners The bankruptcy of the company, or that the bankruptcy of the company follows the bankruptcy of the partners because each of the company and the partners has an independent personality from the other.

The subsidiary company acquires eligibility because it becomes a person with something for natural persons, so the company is imposed on duties, has rights, owns, and the ability to enter into legal ties, to bring cases against others, to be a party to disputes, and in the company's exercise of those functions This is done through the natural persons who represent it, such as the authorized director.

C- Distinguishing the subsidiary company from other entities:

1- Subsidiary company and branches of companies:

There is a similarity between the subsidiary and the branch in that both companies, whether the subsidiary or the branch, are under the control of the holding company, and the two companies achieve the strategy of the holding company through that control and dominance. However, there is a fundamental difference between them, which is as follows:

a) The extent of the legal independence of both companies from the holding company. As for the subsidiary company, it enjoys legal independence from the holding company despite the holding company owning most or all of its shares.

b) This legal independence is demonstrated by the fact that 
it enjoys the capacity to acquire rights, assume obligations and enjoy financial liability independent of the holding company, as well as legal independence in nationality.

In the Canadian Insurance Companies Act of 1991, whereby affiliated insurance companies were permitted to contribute to the capital of their holding companies, in accordance with Article 3 of the Amendment to the Insurance Companies Law issued on May 21, 1992, which stipulates that: (Any company can allow one of the Its subsidiaries may own or hold shares in it if the total value of the share it owns, or all its subsidiaries hold, does not exceed $1 \%$ of the company's statutory capital).

However, it is noted that the Canadian law stipulates that it put a limit on the percentage of the subsidiary's ownership of shares in the capital of the holding company so that it does not exceed $1 \%$ of the capital of the holding company, and this percentage cannot affect the management or control of the holding company over its subsidiaries, and if required Circumstances and through some exceptions that the subsidiary company owns shares in the holding company, there is no objection to the legislator permitting this, but only in cases of necessity, and as an exception, and that it be a small percentage as in the aforementioned Canadian law.

\subsubsection{Effects of the Holding Company's Termination and Its Reflection on the Subsidiary Company}

A- Effect of the holding company's termination:

The holding company is like other companies, it may expire for any reason that leads to the termination of the companies and the termination of the holding company is whether by agreement or through a court ruling, or because of the invalidity of the company, or if the termination of the company is due to the expiration of the company contract, in some case If the contract is for a fixed term, and the partners do not agree to extend the term of the company, or if the purpose for which the company was established has ended, or the company ends with the loss of all its money, or a large part of it so that there is no benefit from its continuation, or the loss of a particular share in particular: As a patent, the company cannot carry out its activity without it, or use a trademark whose use has been found to be illegal; Because it belongs to another person, or in the event of the company's bankruptcy, and until the company is dissolved, the holding company shall retain its legal personality.

This legal personality is not suitable for concluding contracts and legal transactions, as this legal personality is only suitable to the extent that aims to complete the liquidation operations, including the company retaining its name, management center, nationality and domicile, as well as enjoying the capacity to sue and file lawsuits, and the shares of the partners remain owned by the company. It may be seized, and the company may be declared bankrupt during the liquidation period, in case it stops paying its debts.

With regard to the name of the subsidiary company in the event the holding company expires, and the subsidiary company continues to operate as a result of replacing the shareholders of the holding company by new shareholders, the name of the holding company must be amended without such modification including any reference to the expired holding company, in accordance with the name of the new holding company.

As for the subsidiary company of that holding company, by virtue of its affiliation with that holding company, it also follows it in the legal consequences of the expiry of the holding company according to the way in which it acquires and dominates over the subsidiary company and according to the way the holding company controls the management of the subsidiary company and that the holding company's control over the subsidiary be through two things; Either that control is through the holding company owning most or all of the shares of the subsidiary company, or it is through the dominance of the holding company over decision-making in the subsidiary company.

If the holding company owns the largest part of the capital of the subsidiary company, then if the holding company is dissolved and the investors sell shares in the subsidiary company, and new shareholders replace them, the subsidiary company will maintain its legal independence, and the subsidiary company does not revoke, and all that is in the matter is that the control of the subsidiary company lapses The holding company over it, and the subsidiary company continues its activity, but if those in charge of liquidating the holding company want to obtain their share in the capital of the subsidiary company, this will lead to the termination of the subsidiary company.

However, if the holding company owns all the shares of the subsidiary company and the partners in the holding company sell their share to other partners, the subsidiary company will retain its legal entity, but if they wish to recover their share in the subsidiary company, this leads to the end of the subsidiary company, and in the event that If the holding company owns a large part of the capital of the subsidiary company, the expiration of the holding company leads to the expiration of its contribution in the subsidiary company to the extent that it contributes to its capital, and in this case the legal entity of the subsidiary company can continue in the event that the holding company sells its shares In the tab company transferring it to other persons and thereby removing any dominance or control of the holding company over the subsidiary company.

But if the partners in the holding company insist on the expiration and liquidation of the company, then the subsidiary company is terminated and liquidated according to the expiration and liquidation of the holding company. In the second case, it is the dominance of the holding company over the subsidiary company through control and control over the decisions of the subsidiary company without regard to the value of the holding company's contribution to the capital the subsidiary company, the termination of the holding company does not lead to the termination of the subsidiary company, but rather enjoys its independent legal personality.

B- The effect of the holding company's withdrawal:

For any reason for withdrawal, such withdrawal should not involve fraud, as if a holding company withdrew until it gave 
way to another holding company, or a group of natural or legal persons from controlling the subsidiary company to the detriment of the rights of other shareholders in the subsidiary company, or that This withdrawal at an inappropriate time, such as at a time when the subsidiary company is going through bad financial conditions.

And you need to combine the efforts of the holding company wishing to withdraw in order to overcome these difficulties, which could harm the rights of other shareholders or the creditors of the subsidiary company, as the holding company may resort to withdrawing to escape its obligations towards the debts of the subsidiary company by virtue of the holding company's control over the subsidiary company, which leads to To the stability of the liability of the holding company for the debts of the subsidiary company towards third parties, due to the mixing of the financial crisis of the two companies.

A distinction must be made between two cases, the first: the holding company relinquishing its shares in the subsidiary company to another partner. If this other partner is a holding company, then the subsidiary company goes from the first holding company to the second holding company, which replaced the first. The partner is a group of shareholders, whether they are legal persons or natural persons, the subsidiary company loses its status and loses its legal status as a subsidiary company, and continues its activity as a company with legal independence, and in the second case: the withdrawal of the holding company and its request to recover the value of the shares it owns in the capital of the subsidiary company, this leads to the dissolution and expiration of the subsidiary company, and in the event of the holding company withdrawing, and replacing it with another holding company, the subsidiary company changes its name in accordance with the new situation by its subordination to the new holding company, but if the withdrawal is in favor of multiple legal or natural persons that do not own Controlling the subsidiary company, it adjusts its name to suit the new situation and removes the suspicion of its affiliation with the holding company that withdrew.

We conclude from the above that there are different legal forms for the formation of international companies, which may be through a merger between two or more companies, with the same purpose, and a new company is formed thanks to that merger, which is under the control of one of the merged companies, and that merger may take place between companies of different nationalities. With this merger, the legal personality of these companies disappears, to form a new company, which has a new legal personality that differs from the legal personality of the dissolved companies in the merger process.

International companies may be formed through the control of a company called "the parent company" over a company or group of companies called "nascent companies, or subsidiaries", and this control is through the purchase by that parent company of a high percentage of the shares of the capital of the fledgling or affiliated companies. The parent company controls the financial disclosure of these companies, and controls the strategic decisions of these companies in a way that serves the interest of the parent company. As a result of this control, an economic entity with an independent legal personality is born in which the legal personality of those emerging or affiliated companies is merged, and it may have branches spread in a number of Countries, and many legal and economic jurists have differed in the extent to which these fledgling or affiliated companies enjoy a legal personality independent of the legal personality of the parent company.

International companies may resort to controlling other existing companies, in order to benefit from obtaining technology or raw materials and goods that the existing controlled company may produce, and this may be from the parent company controlling at least $50 \%$ of the capital of the existing company. It may be through a natural or legal person, in agreement with a group of shareholders controlling a company, transferring that control to that natural or legal person, and the parent company deals with the subsidiary company as part of the parent company, and the parent company has to intervene in the financial policy The subsidiary company and its continuous control. In return, it finances and lends the subsidiary company through the consolidation of the financial assets of the parent company and the subsidiary company.

\section{Conclusion}

We see through our review of books and research that dealt with the subject of international companies that there is a great practical and scientific effort that has been made by the professors (writers and researchers), although their views differ according to their intellectual and political schools, but all of them dealt with the subject with a scientific methodology, which made it more accommodating to the student and researcher.

We note that international companies realize the amount of power in their hands, they play on better and easier terms, and in practice the dominant companies are increasingly working to determine and accurately their ability to transfer commercial funds, and decide for themselves where to invest and produce? Where do you pay taxes? It pits these potential sites against each other, and leaves the attempt to stop the political flow by offering temptations to these companies to keep their factories in order to reduce the political and social costs of closing these factories, but without any long-term guarantees that these companies will not eventually relocate, and national governments seem increasingly powerless, In front of giant corporations that have long since transcended national borders.

No one can deny the important role that international companies play in developing the global economy, which is why many companies fear them [16].

For countries, this influence by these companies on their economy and the consequent effect on their political decisions will not be exacerbated, due to the huge size of 
these companies and their enjoyment of enormous influence.

We believe that the presence of these companies in the lives of different countries has become an inevitable and inevitable matter, and it cannot be avoided. Rather, countries prefer to go in the direction of more guarantees and privileges granted by projects or international investments wishing to work on their lands. In order to bring capital to it, even if it is in contradiction with the legal principles that are supposed to be followed, or at the expense of national sovereignty without setting any legal controls for it.

It was necessary for us to refute some aspects that are raised about international companies in terms of their definition, emergence, organizational structure and management style through an explanation of the legal regulation of these companies, their relationship with their branches, and their fledgling companies in other countries, and the extent of the strategic and administrative interdependence between the parent company and its fledgling subsidiaries to her.

We have touched on the legal components of the organization of international companies, and they were divided into two sections, the first: of which we talked about the legal regulation of the formation of international companies, and in this section we talked about the different legal forms of the formation of international companies, and it takes several forms, namely: Merger: It is a process that takes place between two companies or More, and one of these companies controls the other companies merging with it so that the legal personality of those companies annihilates, and a new company with a new legal personality is formed, and the financial receivables of those companies are mixed in the new entity, or emerging companies are formed at the international level by a company controlling a company Or other companies in other countries by owning a high percentage of the shares of these controlled companies, and companies may be formed through controlling existing companies by owning more than $50 \%$ of the shares of those companies, which is called control by force, or by agreement with the rest Shareholders in other companies, then we talked about the legal organization of the parent company, through the establishment of subsidiaries of that parent company, or the establishment of new companies that have an independent legal personality [17].

Then we talked about the legal system of the parent holding company, and we talked about the definition of the holding company, which is an integrated economic group, consisting of a mother company, controlling a group of subsidiaries, the legal methods used for the holding company's control over its subsidiaries, as well as the legal effects of the company's control Holding on its subsidiary company, then we talked about the legal organization of the subsidiary company, through the definition of the subsidiary company, as well as its specifications through its being subject to the control of the holding company and its enjoyment of a kind of legal independence such as name, address, and nationality, and its enjoyment of financial responsibility independent of that of the shareholder partners, and its enjoyment of eligibility It imposes duties and has rights, then we talked about the legal consequences of the expiration or withdrawal of the holding company.

The issue of international companies remains open to further treatments and investigations, especially their social aspects, and their effects on the national economy of the host countries. Addressing the advancement of the economies of developing countries, especially Arab countries, and in more practical ways, avoiding waste and reduction of savings and natural resources in these industrialized developed countries, and preserving the environment and sustainable development. In addressing the wide gap between these countries and developed countries.

\section{Recommendations}

1) The need for the state to pay attention to the process of corporate merger, so that it can compete and penetrate other markets, in order to localize advanced technology, and in order to preserve the national industry in the face of major economic blocs.

2) The Egyptian legislator must expressly stipulate that reciprocal participation between the holding company and the subsidiary company is not permissible. In order for each company to maintain its legal personality, it is not permissible for the subsidiary company to have shares in the holding company that would enable it to direct the policy of the holding company.

3) The Egyptian legislator must increase the percentage, which is $20 \%$ of the assets of the fledgling company, which cannot meet that percentage of its debts until the parent company is held accountable for its mistake or arbitrariness in management, because the higher this percentage enables it to deterring the parent company, and forcing its board of directors to work on making good decisions, and not to be arbitrary in decisionmaking; Because these percentages, in my opinion, are insignificant, it is possible that the parent company underestimates the decisions it takes, and thus affects its fledgling company.

4) The Egyptian legislator must develop legislation regulating the responsibility of the parent company for its subsidiaries; Because these international companies are exploiting the lack of legislation to regulate the responsibility of the parent company towards its subsidiaries, as well as in developing countries.

\section{References}

[1] Dr. Anis Muhammad Salih - The Legal System of the Holding Company - A Comparative Study - University of Aden, Republic of Yemen - 2004 AD.

[2] Dr. Hussain Ahmed Al-Jundi: The Legal System for the Settlement of Foreign Investment Disputes in the Light of the Washington Agreement signed in 1965, Dar Al-Nahda AlArabiya press, Egypt. Cairo University, 2003 edition. 
[3] Dr. Hassan Mohamed Hind: The extent of the parent company's responsibility for the debts of its fledgling companies, with special reference to multinational companies, Ph.D. thesis, Faculty of Law, Cairo University, Egypt. 1997.

[4] A d. Samiha Al-Qalyubi: Commercial Companies, Sixth Edition, Dar Al-Nahda Al-Arabiya, Cairo, 2014.

[5] Dr. Okasha Mohamed Abdel Aal, Private International Law, University Press, Alexandria university, Egypt, 2010.

[6] Dr. Abdel Moneim Zamzam, International Bankruptcy between Private International Law and International Trade Law, Arab Renaissance House, Cairo university, 2011.

[7] Dr. Mohamed Ahmed Salam, Corporate Governance and its Role in Attracting Foreign Investments, Dar Al-Nahda AlArabiya press, Cairo university, 2014.

[8] Prof. Muhammad Abdul-Aziz Ajamieh and others - Economic development, theoretical and applied studies, chapter VI, Faculty of Commerce, Alexandria University, Egypt, 2006.

[9] Dr. Naziha Abdel Maqsoud Mabrouk: The Economic Effects of Foreign Investments, A Comparative Study, Dar Al Fikr Al Jamia, Alexandria university, Egypt, 2013.

[10] Dr. Hosni Al-Masry - Merger and division of companies - a comparative study between French and Egyptian law - The
Egyptian Renaissance Library, first edition, Cairo university, Egypt 1986, pg. 43.

[11] Prof. Mohamed Abdel Aziz Agamia and others - Economic development, theoretical and applied studies, sixth semester, Faculty of Commerce, Alexandria University, Egypt, 2006.

[12] International Law on Nationality and the Center for Foreigners, University Press, Alexandria university, Egypt, 2010.

[13] Dr. Tamer Mohamed Ragy: Legal Regulation of International Companies, Ph.D. Thesis, Faculty of Law, Cairo University, Egypt, 2013.

[14] Dr. Badr Ali Bin Ali Al-Jamra: Investment Guarantees According to Egyptian and Yemeni Laws, Ph.D. Thesis, Faculty of Law, Cairo University, Egypt, 2012.

[15] International investment arbitration (substantive principles) Campbell Maclachlan, oxford press.

[16] Principles of International Business Transactions, Trade and Economic Relations, Ralph H. Folsom and Michael Wallace Gordon, THOMSON WEST.

[17] Badr Ali Bin Ali Al-Jamra: Investment Guarantees According to Egyptian and Yemeni Laws, PhD Thesis, Faculty of Law, Cairo University, 2012. 